\title{
1 An evaluation of whale skin differences and its suitability as a tissue for stable
}

2 isotope analysis

3 Running head: Stable isotopes in dorsal and ventral whale skin

4

$5 \quad$ Asunción Borrell ${ }^{1 *}$, Pol Sant ${ }^{1}$, Gísli Víkingsson ${ }^{2}$, Alex Aguilar $^{1}$, Raquel García-Vernet $^{1}$

$6{ }^{1}$ Institute of Biodiversity Research (IRBio) and Department of Evolutionary Biology,

7 Ecology and Environmental Sciences. Faculty of Biology. University of Barcelona.

808028 Barcelona. Spain

$9 \quad{ }^{2}$ Marine and Freshwater Research Institute, P. O. Box 1390, Skúlagata 4, 121 Reykjavík, 10 Iceland.

* corresponding author:

Address: Department of Evolutionary Biology, Ecology and Environmental Sciences, University of Barcelona, Av. Diagonal 643, 08028 Barcelona, Spain.

E-mail address: xonborrell@ub.edu (A. Borrell).

Keywords: stable isotopes; Balaenoptera physalus; epidermis; body position; dorsal; ventral 
Stable isotope analysis of whale skin has been recurrently used to assess diet and movement patterns. Such studies rely on the untested assumption that the stable isotope ratios in the small skin biopsies analysed are representative of those throughout the skin. In balaenopterids, the ventral skin looks notably different from that of the dorsal region, which is smoother and darker. To investigate possible differences in isotopic ratios throughout the skin, we collected and analysed samples from dorsal and ventral positions in 28 fin whales (Balaenoptera physalus). No significant differences were found between these two skin positions, which might suggest that whale skin is likely a homogeneous tissue. Thus, the isotopic ratios determined at a specific point may be representative of the whole skin in whales.

\section{Introduction}

Stable isotope ratios have been widely used to investigate the trophic ecology, habitat use, migration patterns and physiological events of marine mammal populations (e.g., Lesage et al. 2001; Borrell et al. 2006; Drago et al. 2009; Vighi et al. 2014; Borrell et al., 2015; Pinela et al. 2015). However, while the applicability of stable isotopes has been repeatedly tested and analyses of these isotopes are commonly performed, some authors highlighted the need to control factors that can lead to errors in the interpretation of the results (e.g., Barrow et al., 2008; Mill et al. 2008, Ryan et al. 2012; Payo et al. 2013; Yurkowsky et al. 2014). Among the factors that deserve more attention are the suitability and homogeneity of the analysed tissues, due to the limited existing information on this 
The collection of tissues from free-ranging cetaceans is not easy, and biopsy techniques have been developed for this reason (Aguilar and Nadal 1980). The biopsy obtained using darts equipped with a small head-shaped drill usually consists of a small section of the skin that frequently is not sampled in the same site.

The skin is not a uniform tissue but, instead, presents variations in different locations of the body. In balaenopterids, the appearance of the ventral skin is very different to that in the dorsal region, which is smoother, thinner and darker. Despite this obvious variability, the site-specific variation in the skin isotopic ratios of whales has never been analysed. However, knowledge of this variation is central to studies using this tissue.

Hence, the objective of this study was to investigate the possible differences in stable isotope ratios in the skin of fin whales between the two positions reflecting the greatest differences in skin characteristics: the dorsal and ventral regions. We hypothesized that if skin isotope ratios were compared among sites across the body, then ventral and dorsal skin should be the most different. For this reason, we chose these two positions, even though it is not easy to get skin biopsies from the ventral side of the whales. However, in some special circumstances, only the ventral part of the animal might be accessible to sample the skin, such as in standings where the specimens were upside down or when the dorsal part had been predated, or even in dead animals floating in the water.

\section{Materials and Methods}

Skin samples from 2 body positions (dorsal and ventral; Figure 1) were obtained from 28 fin whales caught off of $\mathrm{W}$ Iceland and processed by legal commercial whaling operations at the Hvalur H/F whaling station (Hvalfjörður, Iceland) in 2015. 
71 All samples were preserved frozen. Prior to the analyses, skin samples weighing approximately $250 \mathrm{mg}$ were dried at $40^{\circ} \mathrm{C}$ for $24 \mathrm{~h}$ and then ground to a powder with a mortar and pestle. Since lipids may bias the analysis by decreasing $\delta^{13} \mathrm{C}$ values (Yukowski et al. 2014), they were removed from the samples by rinsing the powdered tissue several times with a chloroform/methanol (2:1) solution.

The preparation for isotope analysis followed that of Borrell et al. (2012). After pretreatment, approximately $0.3 \mathrm{mg}$ of each powdered sample was weighed into tin capsules and combusted at $900^{\circ} \mathrm{C}$. Isotopic analyses were carried out by means of analyser/isotope ratio mass spectrometry (EA-IRMS) using a Thermo Finnigan Flash 1112 (CE Elantech, Lakewood, NJ, USA) elemental analyser, coupled to a Delta $\mathrm{C}$ isotope ratio mass spectrometer via a ConFlo III interface (both from Thermo Finnigan, Bremen, Germany).

Carbon isotope ratios are reported relative to Vienna Pee Dee Belemnite limestone (VPDB) and nitrogen relative to AIR. The accuracy for $\delta^{13} \mathrm{C}$ and $\delta^{15} \mathrm{~N}$ measurements were $0.1 \%$ and $0.3 \%$, respectively.

The distribution of the isotope ratios and the presence of outliers were tested graphically through boxplots. Two outliers (one each for the $\delta^{15} \mathrm{~N}$ and $\delta^{13} \mathrm{C}$ values) were removed from the posterior statistical analysis (Figure 2). The normality and homoscedasticity of the data were checked using Lilliefors' and Levene's tests, respectively. Differences in $\delta^{15} \mathrm{~N}$ and $\delta^{13} \mathrm{C}$ mean values between the dorsal and ventral skin were tested by Pairwise Student's t-tests; The relationship between dorsal and ventral skin was calculated using linear regressions. All statistical analyses were conducted with the IBM SPSS 23 software package. 
96

97

98

Boxplots of the obtained $\delta^{13} \mathrm{C}$ and $\delta^{15} \mathrm{~N}$ values by position (ventral and dorsal) are presented in Figure 2. Descriptive statistics were calculated for the ventral and dorsal positions together to summarize the data, with the following results: $\delta^{13} \mathrm{C}$ values ranged from $-20.24 \%$ to $-18.92 \%$ (mean $\pm \mathrm{SD}=-19.41 \pm 0.30 \%$ ) and $\delta^{15} \mathrm{~N}$ values, ranged from $8.27 \%$ to $10.50 \%$ o $($ mean $\pm \mathrm{SD}=9.40 \pm 0.58 \%$ )

Paired-samples $t$-tests did not indicate significant differences in any of the two variables tested $(\mathrm{p}>0.05)$ (Table 1$)$. Moreover, the dorsal and ventral $\delta^{15} \mathrm{~N}, \delta^{13} \mathrm{C}$ values showed a significant positive relationship (Figure 3). The regression slope between $\delta^{15} \mathrm{~N}$ values was not significantly different from 1 and the intercepts from $0(p>0.05)$, whereas the regression slope and the intercepts of $\delta^{13} \mathrm{C}$ values were different from 1 and 0 respectively $(\mathrm{p}<0.05)$

Table 1: Results of paired t-tests between dorsal and ventral skin positions for $\delta^{13} \mathrm{C}$ and $\delta^{15} \mathrm{~N}$ values. Abbreviations: mean: average difference between the two positions, S.D.: standard deviation of the difference between the two positions, S.E. mean: standard error of the mean, 95\% C. I. D.: confidence interval of the difference and the upper and lower boundaries of the confidence interval, t: paired t-test statistic, df: degrees of freedom.

\begin{tabular}{|c|c|c|c|c|c|c|c|c|}
\hline \multirow[b]{3}{*}{ Variables } & \multicolumn{5}{|c|}{ Paired Differences } & \multirow[b]{3}{*}{$\mathrm{t}$} & \multirow[b]{3}{*}{$\mathrm{df}$} & \multirow[b]{3}{*}{ Sig. } \\
\hline & \multirow[b]{2}{*}{ Mean } & \multirow[b]{2}{*}{ S.D. } & \multirow{2}{*}{$\begin{array}{l}\text { S. E. } \\
\text { mean }\end{array}$} & \multicolumn{2}{|c|}{ 95\% C. I. D. } & & & \\
\hline & & & & Lower & Upper & & & \\
\hline$\delta^{15} \mathrm{~N} \mathrm{d-V}$ & -0.02 & 0.28 & 0.05 & -0.13 & 0.10 & -0.29 & 26 & 0.77 \\
\hline$\delta^{13} \mathrm{Cd}-\mathrm{V}$ & -0.11 & 0.28 & 0.05 & -0.23 & 0.01 & -1.93 & 26 & 0.06 \\
\hline
\end{tabular}




\section{Discussion}

121 Stable isotope analysis of mysticete skin has been repeatedly used to assess diet and movement patterns. In most studies, the skin was collected from free-ranging individuals through biopsies (e.g., Gavrilchuk et al. 2014; Wright et al. 2015; Dehn et al. 2016; Das et al. 2017) taken at variable positions (usually dorsally or laterally) on the whales' bodies. Many factors can bias the collection procedure, such as the skill of the collector, the sampling equipment or sampling platform employed and external variables such as weather or animal movements.

Within an individual, skin coloration varies due to local differences in the concentration of melanocytes (Berta et al. 2015; Perrin 2017). In fin whales, the dorsal skin is black or dark brownish grey, while the ventral skin is white (Aguilar and García-Vernet 2017). Additionally, the epidermis exhibits differences in thickness depending on the position due to differences in dermal papilla height (Jones and Pfeiffer 1994). In fin whales specifically, the epidermis is quite thick across the general body surface, with a thickness varying from a maximum of $3.0 \mathrm{~mm}$ over the ventral surface to $2.5 \mathrm{~mm}$ on the back (Giacometti 1967). Studies conducted on dolphins indicate the importance of the thickness of the skin when calculating the turnover time of the epidermal cells (Brown et al. 1983; Hicks et al. 1985). Therefore, variations in the thickness of the dorsal and ventral skin in fin whales could result in differences in the renewal rates of distinct skin positions, leading to dissimilar isotope values.

Moreover, in balaenopterids, the anterior ventral blubber forms semi-elastic feeding grooves, which permit distension of the mouth and throat while feeding (Shadwick et al., 2013; Gomez-Campos et al., 2016). This morphology implies that blubber from this region is composed of abundant structural collagen and has a lower lipid content than that of the dorsal posterior region in fin, sei (B. borealis), and common minke whales $(B$. 
acutorostrata) (Watanabe and Suzuki 1950; Lockyer et al. 1984, 1985; Kvadsheim et al. 1996). These observations indicate that the dorsal posterior region is the main body location for energy storage in balaneopterids (Lockyer et al. 1985; Víkingsson 1995).

Regarding the isotopic composition of the skin, the current study did not show any significant difference between the two skin positions, although the variation between paired samples was higher for $\delta^{13} \mathrm{C}$ than for $\delta^{15}$ Nvalues. We did not find any explanation for these results, but we hypothesize that differences in the proportions of proteins present in the ventral and dorsal zones may have a stronger effect on $\delta^{13} \mathrm{C}$ than on $\delta^{15} \mathrm{~N}$ values. Nevertheless, additional studies will be needed to explain this difference. Despite this observation, the values for both $\delta^{15} \mathrm{~N}$ and $\delta^{13} \mathrm{C}$ were significantly correlated at the two positions (Figure 3). These correlations, together with the fact that no significant differences were found between paired samples, might suggest that the skin is sufficiently homogeneous to allow comparisons of samples taken from diverse positions of the epidermis in the same study.

Two previous studies have analysed the isotopic differences between different skin positions in three species of dolphins: bottlenose, striped and common dolphins (Williams et al. 2008, Arregui et al. 2017). Both studies evaluated a greater number of positions but considered a smaller number of individuals per species than the current study. In bottlenose dolphins, Williams et al. (2008) compared the isotopic ratios among four skin positions (the dorsal fin, a mid-thoracic site parallel to the dorsal fin, the leading edge of the fluke, and the dorsal surface of the fluke) in two individuals. In common and striped dolphins, Arregui et al. (2017) studied the differences between 11 skin positions: four dorsal positions, three lateral positions, and four ventral positions. The results of these two studies did not indicate significant differences in isotope ratios between positions, and the authors concluded that isotopic homogeneity existed throughout the 
body in these three dolphin species, in agreement with the results obtained in the current study.

\section{Conclusions}

Homogeneity of isotope ratios throughout tissues is a potential concern. We examined two sites of fin whale skin and did not find a difference between ventral and dorsal skin so, maybe homogeneity of skin tissue is not a huge concern within the bounds of normal sampling protocols which at least attempt to sample within a relatively confined area of the animal.

\section{Acknowledgements}

Samples were provided by the Marine and Freshwater Research Institute of Iceland

(MFRI- Hafrannsóknastofnun). The authors are grateful to the personnel of the MFRI who conducted the fieldwork as well as the staff of the Centres Científics i Tecnològics (CCiT-UB) of the University of Barcelona, where the stable isotope ratio determinations were carried out. This work was supported by project CGL2015-70468-R (MINECO/FEDER, UE). The samples originating from Iceland were imported under CITES Import permit number ES-BB 00207/151.

\section{References}

Aguilar, A. and J. Nadal. 1984. Obtención de biopsias hipodérmicas de cetáceos en libertad. Investigación Pesquera 48(1):23-9.

Aguilar, A. and R. García-Vernet. 2017. Fin Whale, Balaenoptera physalus. Pages 368371 in B. Würsig, J. G. M. Thewissen and K. M. Kovaks eds. Encyclopedia of Marine Mammals (Third Edition). Academic Press. San Diego (USA). ISBN: 9780-12-804327-1.

Arregui, M., M. Josa, A. Aguilar and A. Borrell. 2017. Isotopic homogeneity throughout the skin in small cetaceans. Rapid Communications of Mass Spectrometry 31: 1551-1557. doi: 10.1002/rcm.7936 
Barrow, L. M., K. A. Bjorndal and K. J. Reich. 2008. Effects of preservation method on stable carbon and nitrogen isotope values. Physiology and Biochemical Zoology 81(5): 688 - 693. doi: 10.1086/588172

Berta, A., J. L. Sumich and K. M. Kovacs. 2015. Chapter 7. Integumentary and sensory systems, Pages 169-201. In Marine Mammals: Evolutionary Biology.

Borrell, A., N. Abad-Oliva, E. Gómez-Campos, J. Giménez, and A. Aguilar. 2012. Discrimination of stable isotopes in fin whale tissues and application to diet assessment in cetaceans. Rapid Communications of Mass Spectrometry 26 (14): 1596-1602. doi: 10.1002/rcm.6267

Borrell, A., A. Aguilar, V. Tornero, M. Sequeira, G. Fernandez and S. Alís. 2006. Organochlorine compounds and stable isotopes indicate bottlenose dolphin subpopulation structure around the Iberian Peninsula. Environment International 32: 516-523. doi: 10.1016/j.envint.2005.12.001

Borrell, A., E. Gómez-Campos and A. Aguilar, 2016. Influence of Reproduction on Stable-Isotope Ratios: Nitrogen and Carbon Isotope Discrimination between Mothers, Fetuses, and Milk in the Fin Whale, a Capital Breeder. Physiological and Biochemical Zoology, 89(1), 41-50.

Brown, W. R., J. R. Geraci, B. D. Hicks, D. J. St. Aubin and J. P. Schroeder. 1983. Epidermal cell proliferation in the bottlenose dolphin (Tursiops truncatus). Canadian Journal of Zoology 61: 1587 - 1590.

Das, K., O. Holleville, C. Ryan, S. Berrow, A. Gilles, D. Ody, and L. N. Michel. 2017. Isotopic niches of fin whales from the Mediterranean Sea and the Celtic Sea (North Atlantic). Marine Environmental Research 127: 75-83. doi: 10.1016/j.marenvres.2017.03.009

Dehn, L. A., E. H. Follmann, C. Rosa, L. K. Duffy, D. L. Thomas, G. R. Bratton, ... and T. M. O'Hara. 2006. Stable isotope and trace element status of subsistence-hunted bowhead and beluga whales in Alaska and gray whales in Chukotka. Marine Pollutant Bulletin 52 (3): 301-319. doi: 10.1016/j.marpolbul.2005.09.001

Drago, M., E. A. Crespo, A. Aguilar, L. Cardona, N. García, S. L. Dans, and N. Goodall. 2009. Historic diet change of the South American sea lion in Patagonia as revealed by isotopic analysis. Marine Ecology Progress Series 384: 273-286. doi: $10.3354 /$ meps 08017

Gavrilchuk, K., V. Lesage, C. Ramp, R. Sears, M. Bérubé, S. Bearhop, and G. Beauplet. 2014. Trophic niche partitioning among sympatric baleen whale species following the collapse of ground fish stocks in the Northwest Atlantic. Marine Ecology Progress Series 497: 285-301. doi: 10.3354/meps10578

Giacometti, L. 1967. The skin of the whale (Balaenoptera physalus). The Anatomical Record 159(1): 69-75. doi: 10.1002/ar.1091590110

Gómez-Campos, E., A. Borrell, J. Correas and A. Aguilar. 2015. Topographical variation in lipid content and morphological structure of the blubber in the striped dolphin. Scientia Marina 79(2): 189-197. 
Hicks, B. D., D. J. St. Aubin, J. R. Geraci and W. R. Brown. 1985. Epidermal Growth in the Bottlenose Dolphin, Tursiops truncatus. Journal of Investigative Dermatology 85: 60-63.

Hussey, N. E., D. D. Chapman, E. Donnelly, D. L. Abercrombie and A. T. Fisk. 2011. Fin-icky samples: an assessment of shark fin as a source material for stable isotope analysis. Limnology and Oceanography: Methods 9(11): 524-532. doi: 10.4319/lom.2011.9.524

Jones, F. M., and C. J. Pfeiffer. 1994. Morphometric comparison of the epidermis in several cetacean species. Aquatic Mammals 20(1): 29-34.

Kvadsheim, P. H., L. P. Folkow, and A. S. Blix. 1996. Thermal conductivity of minke whale blubber. Journal of Thermal Biology 21: 123-128. doi: 10.1016/03064565(95)00034-8

Lesage, V., M. O. Hammill, and K. M. Kovacs. 2001. Marine mammals and the community structure of the estuary and gulf of St Lawrence, Canada: evidence from stable isotope analysis. Marine Ecology Progress Series 210: 203-221.

Lockyer, C. H., L. C. McConnell, and T. D. Waters. 1985. Body condition in terms of anatomical and biochemical assessment of body fat in North Atlantic fin and sei whales. Canadian Journal of Zoology 63: 2328-2338. doi: 10.1139/z85-345

Lockyer, C. H., L. C. McConnell, and T. D. Waters. 1984. The biochemical composition of fin whale blubber. Canadian Journal of Zoology 62: 2553-2562. doi: $10.1139 / \mathrm{z} 84-373$

Mill, A. C., C. J. Sweeting, C. Barnes, S. H. Al-Habsi and M. A. MacNeil. 2008. Mass-spectrometer bias in stable isotope ecology. Limnology and Oceanography Methods 6(1): 34-39. doi: 10.4319/lom.2008.6.34

Payo-Payo, A., B. Ruiz, L. Cardona and A. Borrell. 2013. Effect of tissue decomposition on stable isotope signatures of striped dolphins Stenella coeruleoalba and loggerhead sea turtles Caretta caretta. Aquatic Biology 18(2): 141-147. doi: $10.3354 / \mathrm{ab} 00497$

Perrin, W. F. 2017. Coloration. Pages 200-205 in B. Würsig, J. G. M. Thewissen and K. M. Kovaks eds. Encyclopaedia of Marine Mammals. (Third Edition). Academic Press. San Diego (USA). ISBN: 978-0-12-804327-1.

Pinela, A. M., A. Borrell and A. Aguilar. 2015. Variation in $\delta^{15} \mathrm{~N}$ and $\delta^{13} \mathrm{C}$ stable isotope values in common dolphins (Delphinus spp.) worldwide, with particular emphasis on the eastern North Atlantic populations. Rapid Communications of Mass Spectrometry 29: 855-863. doi: 10.1002/rcm.7173

Ryan, C., B. McHugh, C. N. Trueman, C. Harrod, S. D. Berrow and I. O'Connor. 2012. Accounting for the effects of lipids in stable isotope $\left(\delta^{13} \mathrm{C}\right.$ and $\delta^{15} \mathrm{~N}$ values $)$ analysis of skin and blubber of balaenopterid whales. Rapid Communications of Mass Spectrometry 26(23): 2745-2754. doi: 10.1002/rcm.6394 
Todd, S. K., B. Holm, D. A. Rosen and D. J. Tollit, 2010. Stable isotope signal homogeneity and differences between and within pinniped muscle and skin. Marine Mammal Science 26(1): 176-185. doi: 10.1111/j.1748-7692.2009.00345.x

Shadwick, R. E., J. A. Goldbogen, J. Potvin, N. D. Pyenson and A. W. Vogl. 2013. Novel muscle and connective tissue design enables high extensibility and controls engulfment volume in lunge-feeding rorqual whales. Journal of Experimental Biology 216(14): 2691-2701. doi:10.1242/jeb.081752

Vighi, M., A. Borrell, E. Crespo, L. R. Oliveira, P. C. Simões Lopes, P. A. C. Flores, N. A. García and A. Aguilar. 2014. Stable isotopes indicate population structuring in the Southwest Atlantic population of right whales (Eubalaena australis). Plos One 9(3): e90489. doi: 10.1371/journal.pone.0090489

Víkingsson, G. A. 1995. Body condition of fin whales during summer off Iceland. Pages 361-369 in Whales, seals, fish and man. Elsevier Science B.V

Watanabe H. and K. Suzuki. 1950. Chemical composition of various parts of whale. Bulletin of the Japanese Society for the Science of Fish 15: 741-743.

Williams, T. M., R. Dunkin, P. Yochem, J. McBain, K. Fox-Dobbs, H. MostmanLiwanag, and J. Maresh. 2008. Assessing stable isotope signature variation in cetaceans: an evaluation of skin sampling techniques and correlations with diet for bottlenose dolphins and killer whales. NWFSC Contract Report. doi: 10.1017/CBO9781107415324.004.

Wright, D. L., B. Witteveen, K. Wynne, and L. Horstmann-Dehn. 2015. Evidence of two subaggregations of humpback whales on the Kodiak, Alaska, feeding ground revealed from stable isotope analysis. Marine Mammal Science 31(4): 1378-1400. doi: $10.1111 / \mathrm{mms} .12227$

Yurkowski, D. J., N. E. Hussey, C. Semeniuk, S. H. Ferguson and A. T. Fisk. 2014. Effects of lipid extraction and the utility of lipid normalization models on $\delta^{13} \mathrm{C}$ and $\delta^{15} \mathrm{~N}$ values in Arctic marine mammal tissues. Polar Biology 38 (2): 131-143. doi: $10.1007 / \mathrm{s} 00300-014-1571-1$ 
308 Fig. 2. Boxplot distribution of $\delta^{13} \mathrm{C}$ and $\delta^{15} \mathrm{~N}$ values determined in the dorsal (D) and 309 ventral (V) skin of fin whales. The top and bottom boundaries of each box indicate the 31075 th and 25th quartile values, respectively, and lines within each box represent the 50th

311 Fig. 3. Paired comparisons between dorsal and ventral positions for the variables $\delta^{15} \mathrm{~N}$, $312 \quad \delta^{13} \mathrm{C}$.. The red diagonal line indicates a 1:1 relationship. The black trend line for $\delta^{15} \mathrm{~N}$ is 313 modelled with the equation $\mathrm{y}=0.93 \mathrm{x}+0.63\left(r^{2}=0.787, p<0.001 ; n=27\right)$, while for $\delta^{13} \mathrm{C}$, $314 \mathrm{y}=0.60 \mathrm{x}-8.48\left(r^{2}=0.364, p<0.01 ; n=27\right)$. 